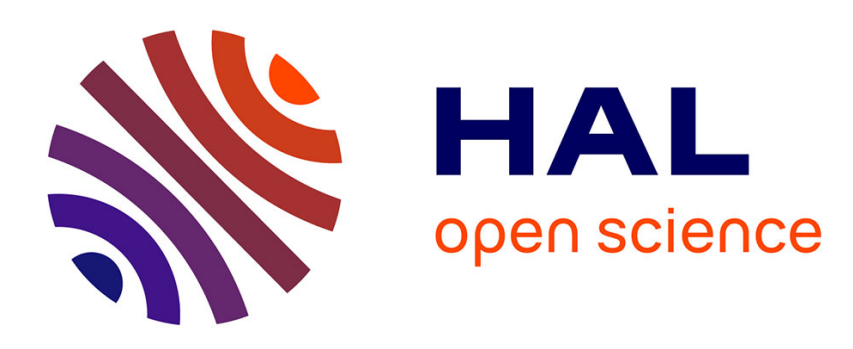

\title{
A study of salmon (Oncorhynchus tschawytscha) pituitary gonadotropin dissociation
}

Bernard Breton

\section{To cite this version:}

Bernard Breton. A study of salmon (Oncorhynchus tschawytscha) pituitary gonadotropin dissociation. General and Comparative Endocrinology, 1981, 45 (2), pp.147-152. 10.1016/0016-6480(81)90098-8 . hal-01600948

\section{HAL Id: hal-01600948 \\ https://hal.science/hal-01600948}

Submitted on 2 Jun 2020

HAL is a multi-disciplinary open access archive for the deposit and dissemination of scientific research documents, whether they are published or not. The documents may come from teaching and research institutions in France or abroad, or from public or private research centers.
L'archive ouverte pluridisciplinaire HAL, est destinée au dépôt et à la diffusion de documents scientifiques de niveau recherche, publiés ou non, émanant des établissements d'enseignement et de recherche français ou étrangers, des laboratoires publics ou privés.

\section{다(1)(2)}

Distributed under a Creative Commons Attribution - ShareAlikel 4.0 International 


\title{
A Study of Salmon (Oncorhynchus tschawytscha) Pituitary Gonadotropin Dissociation
}

\author{
B. BRETON \\ Laboratoire de Physiologie des Poissons, INRA, Campus de Beaulieu, 35042 Rennes, France
}

Accepted December 11, 1980

\begin{abstract}
Urea $(8 M)$ treatment of salmon gonadotropin results in the dissociation of the hormone into two subunits. These subunits were separated using DEAE-cellulose chromatography and gel filtration on Ultrogel ACA 54, and studied for their molecular weights, electrophoretic, biological, and immunological properties. Molecular weights of the $\alpha$ and $\beta$ subunits were, respectively, 12,500 and 17,000 as determined by gel filtration and sodium dodecyl sulfate-gel electrophoresis. In anionic polyacrylamide gel electrophoresis, 7.5\%, the $\alpha$ subunit, migrated more rapidly $\left(R_{f}=0.67\right)$ than the native hormone s-GtH $\left(R_{f}=0.38\right)$, and the $\beta$ subunit did not migrate. The biological activities of the $\alpha$ and $\beta$ subunits were less than $10 \%$ of the GtH. Reassociation allowed a $30 \%$ recovery of the initial biological activity. The immunological properties studied on two radioimmunological systems specifically directed against s- and $\mathrm{cGtH}$, show that immunological determinants were connected with the $\beta$ subunit, which also possesses characteristics of zoological specificity.
\end{abstract}

That the dissociation of glycoprotein hormone into $\alpha$ and $\beta$ subunits is a general phenomenon in vertebrates has been clearly demonstrated in mammals with LH and FSH (de la Llosa et al., 1967; Ward et al., 1971, Reichert and Ward, 1974) and in reptiles and amphibians (see review by Licht et al., 1977). There are clear indications that this process also exists in fish, but up to now it has only been demonstrated in two species: a teleostean (carp, BurzawaGerard, 1974) and a chondrostean (sturgeon, Burzawa-Gerard et al., 1975). Some results have suggested hormonal dissociation in salmon (Donaldson et al., 1972; Idler et al., 1975; Salesse et al., 1978), but the subunits have never been separated or their properties studied. This paper presents some results on gonadotropin subunits in salmon (Oncorhynchus tschawytscha).

\section{MATERIAL AND METHODS}

Gonadotropin purification. Salmon pituitary gonadotropin was purified from pituitaries collected at the Springfield Hatchery in Oregon during the spawning season. The glands were dry-frozen as soon as they were collected.

The method of gonadotropin purification has already been described (Breton et al., 1978). It derives from that described by Idler et al. (1975) and includes buffer extraction, glycoprotein separation using affinity chromatography on a concanavalin A Sepharose $(2 \times$ 40-cm column), gel filtration on ACA 54 Ultrogel $(5 \times$ $100-\mathrm{cm}$ column), ion-exchange chromatography on DEAE-cellulose $(1.6 \times 20-\mathrm{cm}$ column $)$, and a second gel filtration on ACA 54 Ultrogel. In the present work, we have added another purification step using affinity chromatography on wheat germ lectin (WGL) $6 \mathrm{MB}$ Sepharose (Pharmacia) $(0.9 \times 10-\mathrm{cm}$ column). This chromatography, which selectively separates glycoprotein containing $N$-acetyl glucosamine, was performed in a $0.05 \mathrm{M}$ Tris buffer, $\mathrm{pH} 7.8$, containing 1 $\mathrm{m} M$ of $\mathrm{CaCl}_{2}, \mathrm{MgCl}_{2}$, and $\mathrm{MnCl}_{2}$.

The proteins retained on the WGL were eluted using the same buffer containing $0.1 \mathrm{MN}$-acetyl glucosamine (Sigma).

Subunit separation. s-GtH $(2.24 \mathrm{mg}(0.56 \mathrm{mg} / \mathrm{ml}))$ was dialyzed overnight at $4^{\circ} \mathrm{C}$ against $0.05 \mathrm{M}$ Tris $-\mathrm{HCl}$ buffer, $\mathrm{pH}$ 7.8. Solid urea was added to the solution up to $8 M$, and the solution was left at room temperature for $24 \mathrm{hr}$. The resulting mixture was deposited on a DEAE - cellulose Bio-Gel A $(0.9 \times 10 \mathrm{~cm})$ column equilibrated with the Tris buffer and eluted using an ionic strength gradient $(60 \mathrm{ml}$ of $0.05 \mathrm{M}$ Tris $-60 \mathrm{ml}$ of $0.6 \mathrm{M} \mathrm{Nacl}$ ) at a flow rate of $4 \mathrm{ml} / \mathrm{hr}$; 1.5-ml fractions were collected.

The retained and nonretained fractions were pooled and concentrated in an Amicon cell using a UM05 Diaflo membrane, then chromatographed on an ACA 54 Ultrogel column $0.9 \times 60 \mathrm{~cm}$. Standardization of the column was obtained by running a mixture of bovine 
serum albumin fraction $\mathrm{V}$, ovalbumin, chymotrypsinogen, and cytochrome $c$ (Boerhinger calibration kit size II).

Subunit studies. The biological activity of the products was measured using the in vitro trout oocyte maturation assay (Jalabert et al., 1974).

All the fractions were studied for their electrophoretic properties in $7.5 \%$ polyacrylamide gel electrophoresis at pH 9.1 according to Ornstein (1964) and in sodium dodecyl sulfate-gel electrophoresis standardized with the same protein mixture as the ACA 54 Ultrogel column. All the fractions were deposited in the same quantities on the gels $(75 \mu \mathrm{g})$.

The subunits were reassociated by mixing equal quantities $(0.5 \mathrm{mg})$ of the two DEAE-cellulose chromatographic fractions in $0.05 \mathrm{M}$ phosphate buffer, $\mathrm{pH} 7.6$, for $1 \mathrm{hr}$ at a final concentration of $1 \mathrm{mg} / \mathrm{ml}$.

We also studied the immunological properties of s-GtH and its subunits by competition in two specific radioimmunological assays developed for carp (Breton et al., 1971) and trout (Breton et al., 1975) GtH. Using covariance analysis (Snedecor and Cochran, 1957), we compared the slope of the displacement curves for each compound to those obtained with the hormone reference, and we also determined the dose which induced $50 \%$ of binding inhibition.

\section{RESULTS}

Biochemical properties. Affinity chromatography on the WGL of the s-GtH preparation showed a 2.25 -fold increase in biological activity. Before this chromatography, polyacrylamide gel electrophoresis revealed one major $\left(R_{f}=0.38\right)$ and one minor $\left(R_{f}=0.44\right)$ strip. This strip which represented about $5 \%$ of the total protein deposited disappeared after WGL chromatography. After $8 M$ urea treatment, the major strip remained thin, and a more electropositive component $\left(R_{f}=0.67\right)$ appeared.

DEAE-cellulose ion-exchange chromatography of the $8 M$ urea-treated s-GtH gave two peaks: a first nonadsorbed peak (1) and a second peak (2) eluted at $0.13 \mathrm{M}$ ionic strength. With the same chromatographic conditions, the native s-GtH was eluted at about $0.1 \mathrm{M}$.

The two DEAE - cellulose chromatography components run separately on the same ACA 54 column $(0.9 \times 60 \mathrm{~cm})$ gave only one peak whose $K_{\mathrm{d}}$ corresponded to an ap- parently equivalent molecular weight of between 16, and 17,000. Peak 1 of these components revealed only one strip with polyacrylamide gel electrophoresis $\left(R_{f}=\right.$ $0.67)$; peak 2 did not migrate under our electrophoretic conditions. When compared with the results obtained on carp GtH (Burzawa-Gerard, 1974), the first peak would correspond to the $\alpha$-sGtH subunit and the second to the $\beta$ subunit.

Sodium dodecyl sulfate electrophoresis showed the molecular weight of the $\alpha$ and the $\beta$ subunits to be 12,500 and 17,000 , respectively.

Polyacrylamide gel electrophoresis of the $\alpha$ - and $\beta$-subunit mixture presented two strips of equal intensity, corresponding to those of the native hormone and the $\alpha$ subunit. This result indicates incomplete recombination. The percentage of recombination was not determined.

Biological and immunological properties. Table 1 shows the biological activity of the native hormone and its dissociation and recombination products. The results are expressed as the dose needed to induce $50 \%$ of maturation in the in vitro trout oocyte maturation assay.

The $\alpha$ and $\beta$ subunits did not present a significant biological activity (5.5 and $8.4 \%$, respectively, of the native $\mathrm{sGtH})$. After recombination, only $30 \%$ of the biological activity was regenerated.

The competition curves of $\mathrm{sGtH}$ and $\left[{ }^{125} \mathrm{I}\right] \mathrm{cGtH}$ binding to their specific antibodies against the native hormone and its subunits are shown on Figs. 1 and 2 . In the salmonid model, the slopes of these curves are not significantly different for native sGtH, $\beta$ subunit, and the mixture of $\alpha$ and $\beta$ subunits (Table 2 ). On the contrary, the $\alpha$-subunit curve was not parallel as compared to that of the native hormone. The immunological activity expressed by the dose inducing a 50\% inhibition was the same for sGtH, $\beta$-sGtH, and $\alpha+\beta-\mathrm{sGtH}$.

In the carp RIA, no curves were parallel to those obtained with the standard $\mathrm{cGtH}$, 
TABLE 1

EfFicient Dose $\left(\mathrm{D}_{5, \pi}\right)$ Which Induced $50 \%$ of Trout Oocyte Maturation in Vitro Means and 95\% CONFIDENCE LiMits IN $\mathrm{ng} / \mathrm{ml}$

\begin{tabular}{cccccccc}
\hline \multicolumn{2}{c}{ sGtH } & \multicolumn{2}{c}{$\alpha$-sGtH } & \multicolumn{2}{c}{$\beta$-sGtH } & \multicolumn{2}{c}{$\alpha+\beta$-sGtH } \\
\hline \multirow{3}{*}{40} & 36 & & 661 & & 433 & & 125 \\
& & 727 & & 476 & & 132 & \\
& 45 & & 798 & & 524 & & 147 \\
\hline
\end{tabular}

although $\beta$-sGtH gave a value of 0.812 , similar to the reference slope which was 1.115 (Table 2). The immunological activities of the salmon hormone preparations were also very low (Table 2).

\section{DISCUSSION}

Unlike Idler (Idler and $\mathrm{Ng}, 1979$ ), we found that salmon $\mathrm{GtH}$ can be retained on an immobilized lectin, such as wheat germ lectin. This resulted in the increase, by more than twofold, of the biological activity.

Our results concerning urea salmon GtH dissociation confirm those obtained on carp (Burzawa-Gerard, 1974) and sturgeon
(Burzawa-Gerard et al., 1975) GtH. Dissociation of sGtH can be obtained by $8 \mathrm{M}$ urea treatment. Physicochemical and biological properties of the products obtained after dissociation indicated that they correspond to $\alpha$ and $\beta$ sGtH subunits similar to those described in two other species of fishes (Burzawa-Gerard et al., 1975). The estimated molecular weight of $\alpha$-sGtH was about 12,500 and that of $\beta$-sGtH between 16, and 17,000. As in cGtH (Jolles et al., 1977), the molecular weight of the $\beta$ subunit was higher than that of the $\alpha$ subunit. In the same species, Donaldson et al. (1972) reported a molecular weight of 12,500 for sGtH after an acidic treatment which induced dissociation. Our findings are close to these values but gel filtration did not allow detection of any difference between the molecular weights of the $\alpha$ and $\beta$ components. However, a more sensitive technique, such as SDS-gel electrophoresis, could.

In the present study, the electrophoretic properties were also similar to those of

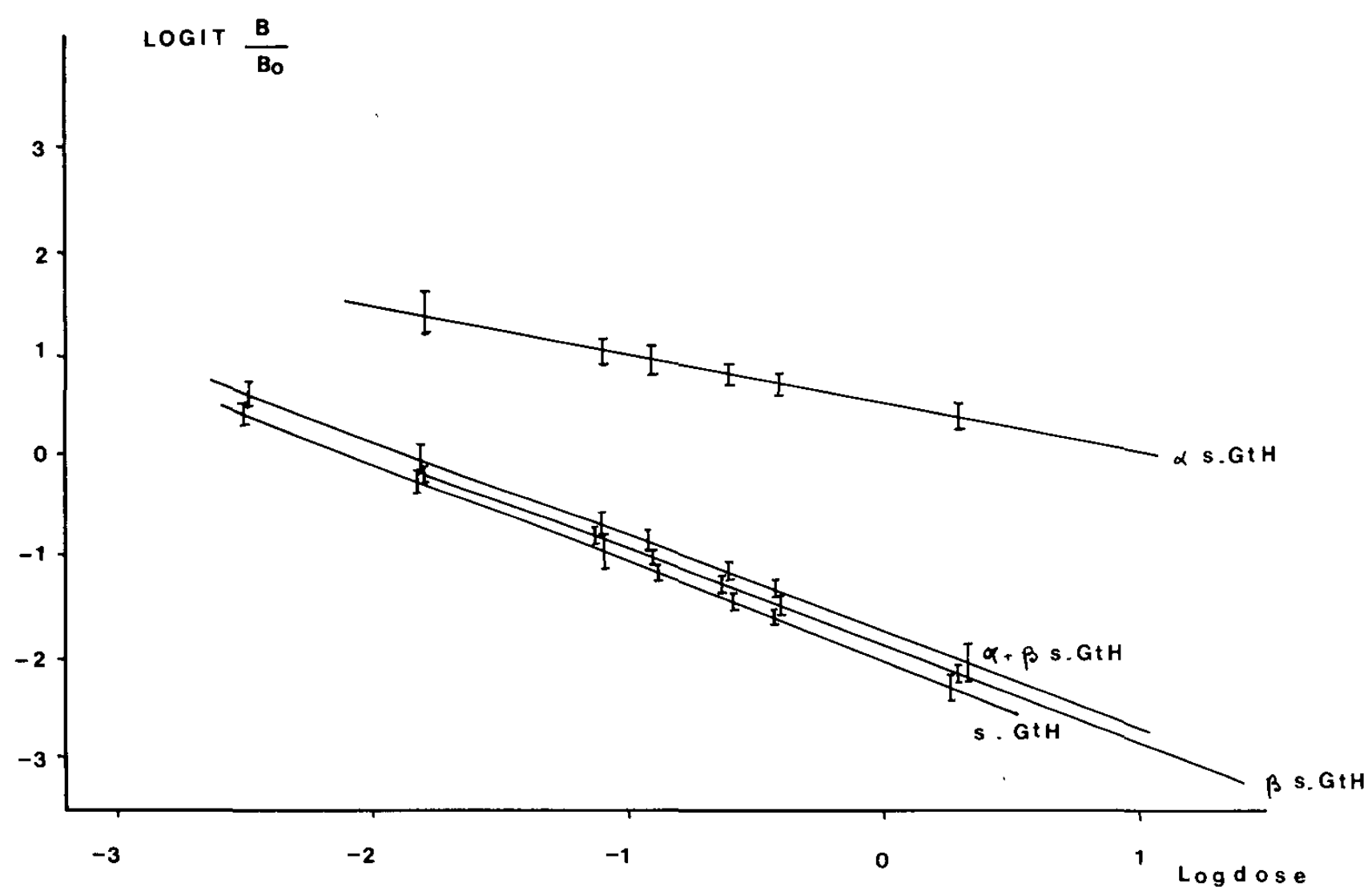

FIG. 1. Displacement curves obtained on trout RIA system. Samples were assayed in triplicate. 


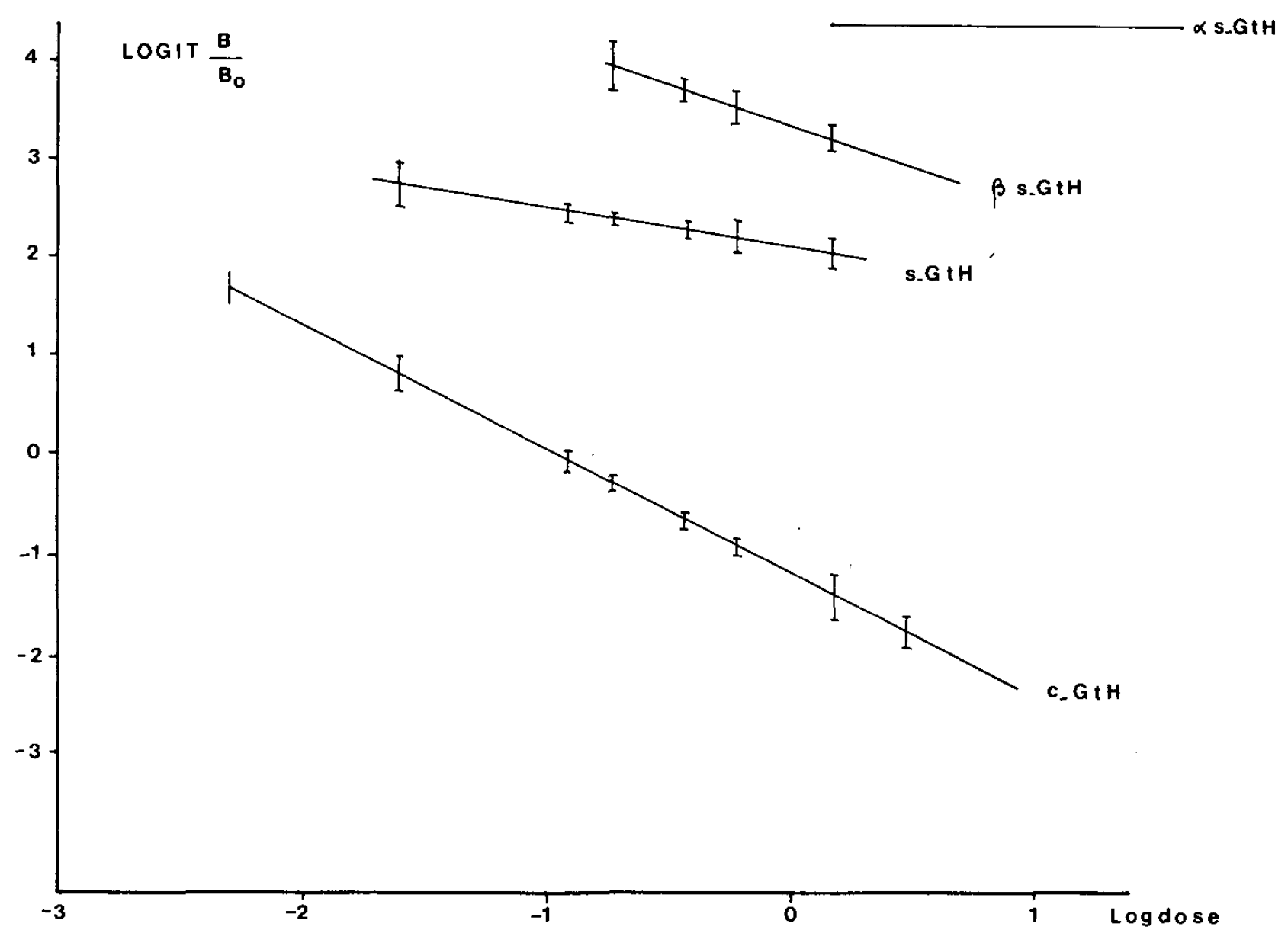

FIG. 2. Displacement curves obtained on carp RIA system.

cGtH where only the $\alpha$ subunits migrate in the anion system; $\alpha$ and $\beta$ aci-GtH subunits, however, would behave very much alike in such a system (Burzawa-Gerard $e t$ al., 1975, 1976). As is the case for gonadotropins in mammals (Papkoff, 1972), amphibians, reptiles (Licht et al., 1977), and fish, such as carp and sturgeon (Burzawa-
Gerard et al., 1975), the biological activity of the s-GtH subunits was very low, while that of the $\beta$-sGtH subunit was slightly higher than that of the $\alpha$-sGtH. After incubation, we recovered only $30 \%$ of the initial biological activity; this value was lower than that obtained in carp and aci-GtH. In fact, we cannot relate this recovery to the

TABLE 2

Slopes of Inhibition Curves Elicited by SGTH and Its Subunits in Two RIA Systems

\begin{tabular}{|c|c|c|c|c|}
\hline \multicolumn{3}{|c|}{ Trout RIA system } & \multicolumn{2}{|c|}{ Carp RIA system } \\
\hline Product & $\begin{array}{c}\text { Slope of the } \\
\text { displacement curves }\end{array}$ & $\begin{array}{l}D_{-1,1} \\
\text { (ng) }\end{array}$ & $\begin{array}{l}\text { Slope of the } \\
\text { displacement curves }\end{array}$ & $\begin{array}{l}\mathrm{D}_{50} \\
(\mathrm{ng})\end{array}$ \\
\hline sGtH & -0.896 & 0.32 & $-0.409^{* *}$ & $<5$ \\
\hline$\alpha$-sGtH & $-0.447^{* *}$ & $<5$ & $0 * *$ & $<5$ \\
\hline$\beta$-sGtH & -0.768 N.S." & 0.40 & $-0.812 * *$ & $<5$ \\
\hline$\alpha+\beta$-sGtH & -0.829 N.S. & 0.42 & & \\
\hline $\mathrm{cGtH}$ & $-0.309 * *$ & $<5$ & -1.115 & 0.38 \\
\hline
\end{tabular}

" $\mathrm{D}_{\bar{\pi} 0}$, dose which inhibited $50 \%$ of binding of the labeled hormone to its specific antibody.

"N.S., not significant.

$* * P<0.005$. 
reassociation rate, which was not determined. Instead, we can assume that it was incomplete since electrophoresis of this recombination showed two strips corresponding to native and $\alpha$-sGtH. In $\mathrm{cGtH}$, the reassociation constant is about 160 -fold more rapid than that of mammalian $\mathrm{LH}$ (Marchelidon et al., 1978, 1974), whereas in sGtH, it is about 5- to 10-fold faster than in oLH (Salesse et al., 1978). Thus, sGtH seems to be more stable than cGtH which dissociated spontaneously (Burzawa-Gerard, 1973). The biological activity of sGtH was retained for 6 months in a solution (Donaldson et al., 1978). It is possible that this stability is related to slower dissociation-association kinetics than in carp. The 1-hr incubation time for sGtH subunit reassociation would not be sufficient to allow total recombination. In addition, we mixed the same quantity of the two subunits (whose molecular weights were different), inducing an excess of one of them, and we did not allow complete recombination.

Immunological results on the carp RIA system confirm our earlier findings concerning the immunological specificity of fish gonadotropins (Breton et al., 1973). This specificity is related to the $\beta$ subunit as in mammals (Kerdelhue et al., 1972) and in carp (Burzawa-Gerard and Kerdelhue, 1978). The cross-reaction between the $\beta$ sGtH and antibody directed against $\mathrm{cGtH}$ seems to indicate that when the GtH's from different species have some common antigenic determinant, they are probably associated with the $\beta$-subunit. The same is true for carp and $\beta$-pLH (Dufour et al., 1979). The $\alpha$ subunit would be more closely related to the zoological specificity.

\section{ACKNOWLEDGMENTS}

This work was supported by the CNEXO which paid for the pituitaries collected.

\section{REFERENCES}

Breton, B., Kann, G., Burzawa-Gerard, E., and Billard, R. (1971). Dosage radioimmunologique d'une hormone gonadotrope de Carpe (Cyprinus carpio L.). C.R. Acad. Sci. Ser. D 272, 1515-1517.

Breton B., Jalabert, B., and Billard, R. (1973). Spécificité d'action zoologique et relations immunologiques des hormones gonadotropes de quelques poissons téléostéens. Ann. Biol. Anim. Biochem. Biophys. 13, 347-362.

Breton, B., Jalabert, B., Fostier, A., and Billard, R. (1975). Etude sur le cycle reproducteur de la Truite arc-en-ciel et de la Tanche. J. Physiol. 70, $561-564$.

Breton, B., Prunet, P., and Reinaud, P. (1978). Sexual differences in salmon gonadotropin. Ann. Biol. Anim. Biochem. Biophys. 18, 759-765.

Burzawa-Gerard, E. (1973). "Etude biologique et biochimique de l'hormone gonadotrope d'un poisson téléostéen la Carpe (Cyprinus carpio L.)," Thèse Doctorat d'Etat Sci. Nat. Paris, VI.

Burzawa-Gerard, E. (1974). Séparation et réassociation des sous-unités de l'hormone gonadotrope d'un poisson téléostéen la Carpe (Cyprinus carpio L.). C.R. Acad. Sci. Ser. D 279, 1681-1684.

Burzawa-Gerard, E., Gondcharov, B., and Fontaine, Y. A. (1975). L'hormone gonadotrope hypophysaire d'un poisson chondrostéen, l'esturgeon (Acipenser stellatus Pall). II. Propriétés biochimiques. Gen. Comp. Endocrinol. 27, 296-304.

Burzawa-Gerard, E., Gondcharov, B., Dumas, A., and Fontaine, Y. A. (1976). Further studies on Carp gonadotropin (c-GtH); Biochemical and biological comparison of $\mathrm{c}-\mathrm{GtH}$ and a gonadotropin from Acipenser stellatus Pall (chondrostéi). Gen. Comp. Endocrinol. 29, 498-505.

Burzawa-Gerard, E., and Kerdelhue, B. (1978). Etude par radioimmunologie des propriétés des immunserums de l'hormone gonadotrope de la Carpe (Cyprinus carpio L.) et de ses sous-unités. Ann. Biol. Anim. Biochem. Biophys. 18, 773-780.

Donaldson, E. M., Yamazaki, F., Dye, H. M., and Philleo, W. W. (1972). Preparation of gonadotropin from Salmon (Oncorhynchus tschawytscha) pituitary glands. Gen. Comp. Endocrinol. 18, 469-481.

Donaldson, E. M., Dye, H. M., and Wright, B. F. (1978). The effects of storage conditions on the biological activity of Salmon gonadotropin. Ann. Biol. Anim. Biochem. Biophys. 18, 997-1000.

Dufour, S., Burzawa-Gerard, E., and Fontaine, Y. A. (1978). Evolution des hormones glycoprotéiques hypophysaires: Données radioimmunologiques sur les sous-unités de l'hormone gonadotrope de Carpe (Cyprinus carpio L.). C.R. Acad. Sci. Ser. D 289, 137-140.

Idler, D. R., Bazar, L. S., and Hwang, S. J. (1975). Fish gonadotropin(s). II. Isolation of gonadotropin from chum salmon pituitary glands using af- 
finity chromatography. Endocrine Res. Commun. 2, 215-235.

Idler, D. R., and Ng, B. T. (1979). Studies on two types of gonadotropins from both Salmon and Carp pituitaries. Gen. Comp. Endocrinol. 38, 421-440.

Jalabert, B., Breton, B., and Billard, R. (1974). Dosage biologique des hormones gonadotropes de poissons par le test de maturation in vitro des ovocytes de Truite. Ann. Biol. Anim. Biochem. Biophys. 14, 217-228.

Jolles, S., Burzawa-Gerard, E., Fontaine, Y. A., and Jolles, P. (1977). The evolution of gonadotropins: Some molecular data concerning a nonmammalian pituitary gonadotropin, the hormone from a teleost fish (Cyprinus carpio L.). Biochimie 59, $893-898$.

Kerdelhue, B., Pistoulis, S., and Jutisz, M. (1972). Immunological properties of antisera against luteinizing hormone and its subunits obtained in guinea pig. In "Structure-Activity Relationships of Protein and Polypeptide Hormones. Proceeding of the Second International Symposium, Liege," Part 2, pp. 396-397. Excerpta Medica, Amsterdam.

Licht, P., Papkoff, H., Farmer, S. W., Muller, C. M., Tsui, H. W., and Crew, D. (1977). Evolution of gonadotropin, structure and function. Rec. Progr. Horm. Res. 33, 169-248.

de la Liosa, P., Courte, C., and Jutisz, M. (1967). On the mechanism of reversible inactivation of luteinizing hormone by urea. Biochem. Biophys. Res. Commun. 26, 411-416.

Marchelidon, J., Fontaine-Bertrand, E., Salesse, R., Garnier, J., Burzawa-Gerard, E., and Fontaine,
Y. A. (1978). Rapidité de la réassociation in vitro des sous-unités de gonadotropine chez un poisson téléostéen la Carpe (Cyprinus carpio L.). C.R. Acad. Sci. Ser. D 287, 301-304.

Marchelidon, J., Salesse, R., Garnier, J., BurzawaGerard, E., and Fontaine, Y. A. (1979). Zoological origin of gonadotropin subunits and association kinetics. Nature (London) 281, 314-315.

Ornstein, L. (1974). Disc electrophoresis. I. Background and theory. Ann. N.Y. Acad. Sci. $121,321$.

Papkoff, H. (1972). The subunit nature of interstitialcell-stimulating hormone. In "Structure-Activity Relationship of Protein and Polypeptide Hormones. Proceeding of the Second International Symposium, Liege,"' Part 1, pp. 73-79. Excerpta Medica, Amsterdam.

Pierce, J. G. (1971). Eli Lilly lecture: The subunits of pituitary thyrotropin their relation to other glycoprotein hormones. Endocrinology 89, 1331-1334.

Reichert, L. D., Jr., and Ward, D. N. (1974). On the isolation and characterization of the alpha and beta subunits of human pituitary follicle stimulating hormone. Endocrinology 94, 655-664.

Salesse, R., Garnier, J., and Breton, B. (1978). Interaction of salmon gonadotropin subunits: Spectroscopic studies. Ann. Biol. Anim. Biochem. Biophys. 18, 767-771.

Snedecor, G. W., and Cochran, W. G. (1957). "Statistical methods." Iowa State Univ. Press, Ames.

Ward, D. N., Reichert, L. E., Jr., Fitak, B. A., Nahm, H. S., Sweeney, C. M., and Neill, J. D. (1971). Isolation and properties of subunits of rat luteinizing hormone. Biochemistry 10, 1796-1802. 